\section{Emergence of Anoxia in the California Current Large Marine Ecosystem}

E ${ }^{1 *}$ ]. A. Barth, ${ }^{2}$ ]. Lubchenco, ${ }^{1}$ A. Kirincich
astern boundary current systems are among the most productive large marine ecosystems in the world. Their productivity arises from wind-driven upwelling of nutrient-rich water into the photic zones of coastal oceans and supports $20 \%$ of global fishery yield (1). Upwelling also transports oxygenpoor waters onto productive continental shelves, where respiration can further reduce watercolumn dissolved oxygen (DO) content and thus subject coastal ecosystems to the risk of hypoxia or anoxia.

Of the world's four major eastern boundary current systems, water-column shelf anoxia is previously known for only the Humboldt and Benguela Current systems (2). Because oxygen deficit can be a critical determinant of fishery, ecological, and biogeochemical processes $(3,4)$, the rise or expansion of hypoxia and anoxia represent major perturbations to the structure and functioning of coastal marine ecosystems. Here, we report the intensification of severe innershelf hypoxia (defined here as $\leq 0.5 \mathrm{ml} \mathrm{l}^{-1}$ ) and the novel rise of water-column anoxia in the California Current large marine ecosystem (CCLME) along the U.S. West Coast.

Following changes in upwelling-favorable winds in 2006, we measured the emergence of anoxia along the central Oregon coast. Anoxia was evident in inner-shelf $(<50 \mathrm{~m})$ stations situated within $2 \mathrm{~km}$ of the surf zone (Fig. 1C). The onset of anoxia was accompanied by the expansion of severe hypoxia across broad sections of the central Oregon shelf. At its largest, hypoxia prevailed across all cross-shelf transect lines between $44.25^{\circ} \mathrm{N}$ and $45.00^{\circ} \mathrm{N}$, extending from the shelf break to the inner shelf and encompassing at least $3000 \mathrm{~km}^{2}$. Hypoxia was persisting over mid- and inner-shelf waters from June to October.

Although severe hypoxia is a permanent feature of the oxygen minimum zone (OMZ) that intersects the continental slope $(>600 \mathrm{~m}$ in this system), there are no prior records of anoxia over the continental shelf or within the OMZ (Fig. 1A). In contrast to OMZ marine life that possess adaptations to severe oxygen stress (3), demersal fish and benthic invertebrate communities in these shallow shelf waters were acutely affected by seasonally persistent anoxia and severe hypoxia. In August 2006, submersiblebased surveys along the same previously monitored (2000 to 2004) transect lines revealed the complete absence of all fish from rocky reefs that normally serve as habitats for diverse rockfish (Sebastes species) communities that are of current fishery management concern. Our surveys also revealed near-complete mortality of macroscopic benthic invertebrates and an accompanying rise of putative sulfide-oxidizing bacterial mats in shallow $(50 \mathrm{~m})$ waters (movie $\mathrm{S} 1$ ).

The rise of anoxia has occurred against a backdrop of recent increases in the frequency and severity of shelf hypoxic events in this system (Fig. 1B). Five decades of available records show little evidence of shelf hypoxia and no evidence of severe inner-shelf hypoxia before 2000 (Fig. 1A). Recent studies indicate that the onset of shelf hypoxia can reflect basin-scale fluctuations in atmosphere-ocean processes that alter the oxygen content of upwelled water, the intensity of upwelling wind stress, and productivity-driven increases in coastal respi- ration $(5,6)$. Strongly coupled atmospheric and oceanic circulation underpins ecosystem dynamics in wind-driven upwelling shelves and ecosystem susceptibility to modulations of upwelling wind stress from climate warming $(7,8)$. The present-day global distribution of shelf anoxia reflects broad cross-system differences in vertical proximity to OMZs, shelf productivity, and circulation. The novel rise of shelf anoxia in the CCLME highlights the potential for rapid reorganization in the distribution of anoxia and the sensitivity of productive upwelling shelves to discontinuous ecosystem change.

\section{References and Notes}

1. D. Pauly, V. Christensen, Nature 374, 255 (1995).

2. J. Helly, L. A. Levin, Deep Sea Res. 51, 1159 (2004).

3. J. J. Childress, B. A. Seibel, J. Exp. Biol. 201, 1223 (1998).

4. L. A. Levin, Oceanogr. Mar. Biol. Annu. Rev. 41, 1 (2003).

5. B. A. Grantham et al., Nature 429, 749 (2004).

6. A. Bakun, S. J. Weeks, Ecol. Lett. 7, 1015 (2004).

7. H. V. McGregor, M. Dima, H. W. Fischer, S. Mulitza, Science 315, 637 (2007).

8. J. A. Barth et al., Proc. Natl. Acad. Sci. U.S.A. 104, 3719 (2007).

9. We thank M. Robart, W. Miller, S. Pierce, and J. Peterson for their assistance. This paper is contribution 273 of the Partnership for Interdisciplinary Studies of Coastal Oceans (PISCO; funded by the David and Lucile Packard Foundation and the Gordon and Betty Moore Foundation) and contribution 582 of the U.S. Global Ocean Ecosystem Dynamics program (funded by NSF and National Oceanic and Atmospheric Administration). Additional support was provided by NSF, the A. W. Mellon Foundation, the Wayne and Gladys Valley Foundation, and the Robert and Betty Lundeen Marine Biology Fund.

\section{Supporting Online Material}

www.sciencemag.org/cgi/content/full/319/5865/920/DC1 Movie S1

9 August 2007; accepted 28 November 2007 10.1126/science. 1149016

${ }^{1}$ Department of Zoology, Oregon State University, Corvallis, OR 97331, USA. ${ }^{2}$ College of Oceanic and Atmospheric Sciences, Oregon State University, Corvallis, OR 97331, USA. ${ }^{3}$ Oregon Department of Fish and Wildlife, Newport, OR 97365, USA. ${ }^{4}$ Northwest Fisheries Science Center, National Oceanic and Atmospheric Administration, Newport, OR 97365, USA.

*To whom correspondence should be addressed. E-mail: chanft@science.oregonstate.edu
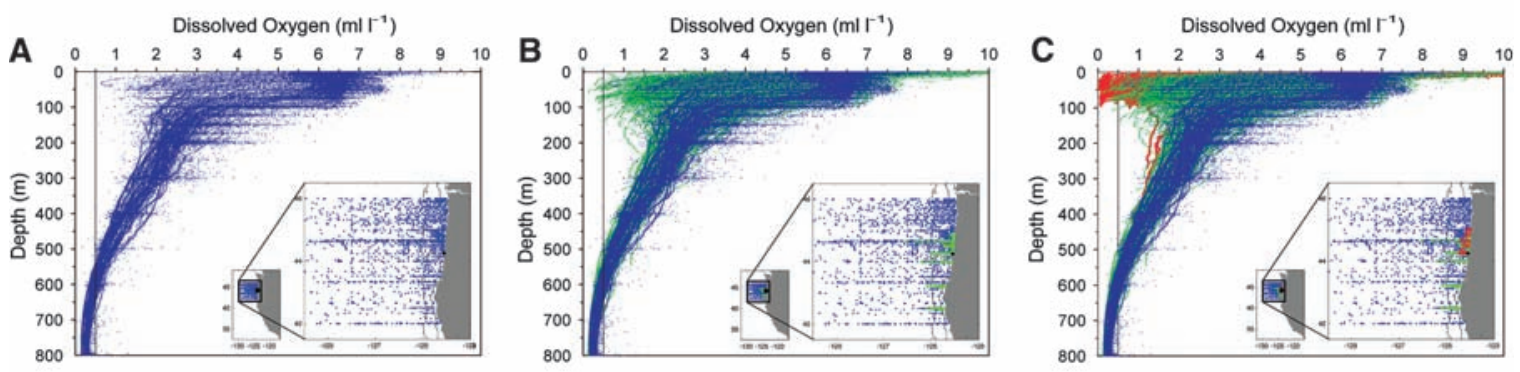

Fig. 1. Dissolved oxygen profiles during the upwelling season (mid-April to mid-October) in the upper $800 \mathrm{~m}$ of the continental shelf and slope of Oregon $\left(42.00^{\circ} \mathrm{N}\right.$ to $\left.46.00^{\circ} \mathrm{N}\right)$. (A) 1950 to 1999 from the World Ocean Database and Oregon State University archives $(n=3101$ hydrocasts, blue). (B) (A) with additional data for 2000 to 2005 ( $n=834$ hydrocasts, green). (C) (A) and (B) plus data for 2006 ( $n=220$ hydrocasts, red). The black vertical line denotes the $0.5 \mathrm{ml} \mathrm{l}^{-1}$ threshold. (Insets) Overlapping locations of hydrographic (blue, green, and red) and remotely operated vehicle (black) stations through time and the $100-\mathrm{m}$ and $1000-\mathrm{m}$ isobaths. 